\author{
St udia Philosophic a \\ Wratis lavien s i a \\ vol. XV, fasc. 1 (2020) \\ https://doi.org/10.19195/1895-8001.15.1.6
}

\author{
WITOLD PŁOTKA
}

ORCID: 0000-0003-1984-3078

Uniwersytet Kardynała Stefana Wyszyńskiego w Warszawie

\title{
Psychologia opisowa na nowo odczytana? Szkic o metodzie w filozofii Leopolda Blausteina*
}

\author{
A New Reading of Descriptive Psychology? An Outline \\ of the Method in Leopold Blaustein's Philosophy
}

\begin{abstract}
The main purpose of the article is to define the framework in which one can situate Leopold Blaustein's philosophy. The author focuses on the question of the method which is used by Blaustein and he situates it in the historical-philosophical context. The article defends the thesis that Blaustein uses a method which can be labelled as a phenomenologically oriented descriptive psychology that is close to, though not identical with, Edmund Husserl's project as formulated in the first edition of his Logical Investigations and that is connected to Husserl's 1925 lectures on the phenomenological psychology. The article is divided into four parts. In the first part, the author disputes the one-sided classifications of Blaustein's philosophy either as a continuator of the analytical tradition of the Lvov-Warsaw School, or as a mere repetition of Husserl's achievements. In the next part, the author sketches an intellectual biography of Blaustein and on this basis he defines the context in which one has to situate this thought. In this regard, two further parts of the article are devoted to two sources of inspiration for Blaustein. In the third part, a selection of methods and concepts of descriptive psychology are examined, and in the last part of the article, references to Husserl's phenomenology are explored.
\end{abstract}

Keywords: descriptive psychology, phenomenological reduction, Blaustein, Twardowski, Husserl

* Badania zostały sfinansowane przez Narodowe Centrum Nauki w ramach projektu „Obecność myśli Kazimierza Twardowskiego we wczesnej fenomenologii w Polsce” (nr 2017/27/B/HS1/02455). 


\section{Wprowadzenie}

Twórczość filozoficzną Leopolda Blausteina trudno jednoznacznie zaklasyfikować. To, że miał on okazję studiować u filozofów, którzy reprezentują różne tradycje, czy to u Kazimierza Twardowskiego we Lwowie, czy też u Edmunda Husserla we Fryburgu Bryzgowijskim, zdaje się sugerować, że w swojej pracy łączył odmienne podejścia metodologiczne. W literaturze przedmiotu sugestia ta znajduje konkretne rozwinięcia, jeżeli chodzi o wpływy zarówno Twardowskiego, jak i Husserla; czasami zbytnio, jak się wydaje, akcentuje się jeden z tych kontekstów i pomija się inne, mniej oczywiste wpływy. Sytuację dodatkowo komplikuje fakt, że rozumienie fenomenologii przez Blausteina było na wskroś krytyczne i w wielu punktach wykraczało poza proste powtórzenie drogi myślowej lub rezultatów badawczych Husserla. Nie dziwi zatem, że w literaturze przedmiotu zdania na temat zasadności klasyfikacji filozofii Blausteina jako odmiany fenomenologii są podzielone. Taką klasyfikację podają w wątpliwość, dajmy na to, Mieczysław Andrzej Dąbrowski ${ }^{1}$ oraz Marek Pokropski ${ }^{2}$. Przeciwnie do nich na przykład Stanisław Pazu$\mathrm{ra}^{3}$, a ostatnio także Maria van der Schaar ${ }^{4}$ jednoznacznie klasyfikują Blausteina jako fenomenologa. Wioletta Miśkiewicz idzie nawet dalej, twierdząc, że jest on twórcą „,całkiem nowej dziedziny fenomenologii”, która jest „analityczna, opisowa i interdyscyplinarna"5. Biorąc pod uwagę te rozbieżne uwagi, podstawowym celem tego artykułu jest próba określenia ram interpretacyjnych, w których można sytuować filozofię Blausteina. Bronię tezy, że adekwatne w tym wypadku jest mówienie o fenomenologicznie zorientowanej psychologii opisowej, pokrewnej, chociaż nie tożsamej z projektem przedstawionym przez Husserla (później zarzuconym) w pierwszym wydaniu jego Badań logicznych oraz nawiązującym do wykładów niemieckiego filozofa z 1925 roku o psychologii fenomenologicznej. Skupiam się przy tym na rozważaniach metodologicznych, przyjmując za samym Blausteinem ${ }^{6}$, że dla pełnego określenia filozofii należy odnieść się do jej metody i przedmiotu.

Aby określić ramy interpretacyjne dla rozumienia metody przez polskiego filozofa artykuł podzielono na cztery części. W pierwszej, polemicznej części artykułu zarysuję nieporozumienia i niejasności, które spotyka się w jednostronnych klasyfikacjach omawianej filozofii. W literaturze przedmiotu filozofię tę często odczytuje się albo w kontekście metody analitycznej Szkoły Lwowsko-Warszawskiej (SLW), albo

${ }^{1}$ Zob. M.A. Dąbrowski, Bibliografia prac Leopolda Blausteina, „Roczniki Filozoficzne” 29 (1981), nr 1 , s. 244.

2 Zob. M. Pokropski, Leopold Blaustein's Critique of Husserl's Early Theory of Intentional Act, Object and Content, ,Studia Phaenomenologica” 15 (2015), s. 94.

${ }^{3}$ Zob. S. Pazura, Blaustein, Leopold, [w:] Słownik Filozofów, t. 1, red. I. Krońska, Warszawa 1966, s. 90 .

${ }^{4}$ Zob. M. van der Schaar, Kazimierz Twardowski: A Grammar for Philosophy, Leiden 2015, s. 12.

${ }^{5}$ W. Miskiewicz, Leopold Blaustein's Analytical Phenomenology, [w:] The Golden Age of Polish Philosophy. Kazimierz Twardowski's Philosophical Legacy, S. Lapointe et al. (red.), Dordrecht 2009, s. 182 .

${ }^{6}$ Zob. L. Blaustein, Edmund Husserl i jego fenomenologia, „Przegląd Humanistyczny” 5 (1930), nr 2, 236; przedruk [w:] Polska fenomenologia przedwojenna. Antologia tekstów, D. Bęben, M. Ples-Bęben (red.), Katowice 2013, s. 227. 
jako jedynie powtórzenie osiągnięć Husserla. Argumentuję, że podobne podejścia w skrajnych formach nie są adekwatne dla zrozumienia metody stosowanej przez Blausteina. W drugiej części artykułu pokrótce przedstawiam elementy biografii intelektualnej polskiego filozofa. Celem tej części jest pełniejsze określenie kontekstów, w których należy sytuować jego koncepcję. Na podstawie tych dociekań w dwóch kolejnych częściach badam główne źródła inspiracji dla Blausteina. I tak w trzeciej części artykułu przyglądam się wybranym metodom i koncepcjom psychologii opisowej, popularnej na przełomie XIX i XX wieku formie badań filozoficznych, którą w Polsce spopularyzował Twardowski. Wpływy te, jak staram się pokazać, owocują w podkreśleniu przez Blausteina wartości empirycznych metod badawczych oraz, jak można przypuszczać, prowadzą do odrzucenia metody redukcji fenomenologicznej. Podobny krok stawia nas przed pytaniem o wykorzystanie przez polskiego filozofa metod opracowanych na gruncie fenomenologii. Dlatego w czwartej części artykułu skupiam się na krytyce fenomenologii sformułowanej przez Blausteina. Stawiam przy tym tezę, że polemiki te skutkują odrzuceniem dużej części metodologii Husserla, lecz, co zaskakujące, prowadzą też do wyraźnych zapożyczeń. Na tej podstawie w zakończeniu kreślę elementy metody psychologii opisowej Blausteina, która zawiera pierwiastki tradycji wywodzącej się zarówno od Brentana i Diltheya, jak i od Husserla.

\section{O dwóch nieporozumieniach wokół filozofii Blausteina}

Filozofię Blausteina często rozważa się w kontekście Twardowskiego i Husserla. Podobny krok interpretacyjny jest bez wątpienia uzasadniony, ale w skrajnych formach może prowadzić do dwóch nieporozumień, które utrudniają zrozumienie specyfiki tej filozofii. Pierwsze nieporozumienie polega na zbytnim, jak się wydaje, wyeksponowaniu wpływów Twardowskiego, a przez to na sugestii, że Blaustein stosował wyłącznie metodę analizy pojęciowej, drugie zaś na ujęciu tego filozofa jako jedynie interpretatora i kontynuatora Husserla. W tej części artykułu polemicznie ustosunkuję się do obu interpretacji.

W nowszej literaturze przedmiotu można się spotkać z ujęciem filozofii Blausteina jako „fenomenologii analitycznej”. Za podobną klasyfikacją przytacza się przede wszystkim argumenty natury historyczno-filozoficznej. Jan Woleński na przykład określa Blausteina „prekursorem fenomenologii analitycznej”, w której filozof ten miał starać się „łączyć idee Twardowskiego i Husserla"”. Propozycja Woleńskiego jest jednak szkicowa. Nie podejmuje on dalszych i pogłębionych badań nad konkretnymi ideami Twardowskiego i Husserla, które miał łączyć Blaustein, a ponadto nie wyjaśnia, na czym polega samo to „połączenie”. Więcej szczegółów można znaleźć w opracowaniu Pokropskiego, który również wiąże polskiego filozofa z „fenomenologią analityczną" i podkreśla, że „oryginalność myślenia Blausteina zasadza się na fakcie pewnej syntezy dwóch tradycji filozoficznych: analitycznej filozofii Twardowskiego (analizy logicznej i pojęciowej) i fenomenologii Husserla (opisu i analizy

7 J. Woleński, Żydzi w filozofii polskiej, „Studia z Filozofii Polskiej” 5 (2010), s. 23. 
aktów świadomości)"». Pokropski uszczegóławia zatem, że filozof ten miał łączyć metodologie obu tradycji filozoficznych: analizę logiczną z analizą fenomenologiczną. Ta pierwsza ma dotyczyć pojęć, ta druga zaś świadomości. Interpretacja ta, chociaż pełniejsza od propozycji Woleńskiego, wciąż wydaje się nieadekwatna, ponieważ Pokropski sugeruje, że wyrażenie „fenomenologia analityczna” odnosi się do faktu korzystania przez Blausteina z dwóch metod, co nie oddaje specyfiki jego podejścia. Poza tym interpretacja ta sprawia wrażenie, że obie metody mają być równie istotne dla polskiego filozofa. Tak jednak nie jest. Nawet pobieżny przegląd prac filozoficznych tego autora jasno pokazuje, że analizy logiczne i pojęciowe w nich nie dominują. Mają raczej charakter marginalny, często wprowadzajacy ${ }^{9}$, a sam filozof jest zainteresowany ostatecznie analizą konkretnych zjawisk psychicznych. Również próba rozumienia wyrażenia ,fenomenologia analityczna” jako nazwy dla dziedziny, która aplikuje analizę pojęciową w fenomenologii, jest nietrafiona. Pokropski posługuje się wąskim znaczeniem ,analityczności”, wiążąc ją z analizą logiczną i pojęciową. Jeżeli weźmie się pod uwagę fakt, że Blaustein krytycznie ustosunkowywał się do postępowania analitycznego w rozumieniu szeroko pojętej SLW, czemu w pewnym zakresie dał wyraz w krytycznej recenzji z Elementów teorii poznania, logiki formalnej $i$ metodologii nauk Tadeusza Kotarbińskiego ${ }^{10}$, wówczas odczytanie Pokropskiego jest problematyczne. Nie bez znaczenia pozostaje także to, że wyrażenie „fenomenologia analityczna”, przy wąskim rozumieniu „,analityczności” jako sposobu rozbioru pojęć, jest sprzeczne, ponieważ wymaga od filozofa przyjęcia metody, która jest nieadekwatna do badania fenomenów, gdyż ogranicza pole badawcze do pojęć. Wątpliwości tych Pokropski nie rozpatruje.

Pokropski ${ }^{11}$ zauważa, że ujęcie filozofii Blausteina jako syntezy myśli Twardowskiego i Husserla w jego oryginalnej „fenomenologii analitycznej” pochodzi od Miśkiewicz. Wbrew tej sugestii Miśkiewicz nie wiąże jednoznacznie filozofii Blausteina z metodą analityczną Twardowskiego jako metodą analizy logicznej i analizy pojęciowej. Miśkiewicz jedynie włącza tę filozofię do tradycji wczesnej fenomenologii opisowej, zamiennie nazywanej przez nią fenomenologią analityczną, która skupia się na pytaniu o źródło i wartość poznania, analizując intencjonalnośćc ${ }^{12}$. Tym samym Miśkiewicz proponuje rozumieć „,analityczność” szerzej od Pokropskiego, a mianowicie jako rygorystyczny rozbiór danego przedmiotu (nie zaś pojęć) analizy. W podobnym

8 M. Pokropski, op. cit., s. 94.

${ }^{9}$ Zob. np. L. Blaustein, Husserlowska nauka o akcie, treści i przedmiocie przedstawienia, Lwów 1928, s. 2, 52; oraz idem, Wybór pism estetycznych, Z. Rosińska (red.), Kraków 2005, s. 47, przypis 12.

${ }^{10}$ Zob. L. Blaustein, Kotarbiński Tadeusz. Elementy teorji poznania, logiki formalnej i metodologji nauk, Lwów Wyd. Zakt. Nar. im Ossolińskich 1929, s. VIII+483, „Przegląd Humanistyczny” 5 (1930), nr $4-5$, s. $456-458$.

11 Zob. M. Pokropski, op. cit., s. 94.

12 „There are at least two kinds of phenomenology: hermeneutic and descriptive. The latter rests on the idea that what is given in conscious experience is direct, akin to perception — what most phenomenologist would have called $»$ intuition « — and is therefore a genuine source of knowledge. The theories of early analytical phenomenologists were aimed at providing an understanding of the latter". W. Miskiewicz, op. cit., s. 181. 
duchu Blausteina ujmuja inni autorzy, na przykład Zofia Rosińska ${ }^{13}$. Bardziej adekwatne wydaje się zatem mówienie o kształtowaniu się koncepcji Blausteina w dyskusji z Twardowskim, przy zachowaniu ogólnych zasad i postulatów postępowania analitycznego. W podobnym tonie Wojciech Chudy zauważa, że filozofia Blausteina wyrasta, jak pisze, z ,podwójnego pnia”: szkoły Twardowskiego i fenomenologii; przy czym, jak zaznacza Chudy, chociaż „brak wyraźnej przynależności [Blausteina W.P.] do którejśs ze szkól”14, bliższa wydaje się mu myśl Twardowskiego.

Drugie nieporozumienie wiąże się ze zbytnim wyróżnieniem drugiego z pni, o których pisze Chudy, to jest z wyróżnienia fenomenologii Husserla. Nieporozumienie to jest wyraźne zarówno u Pokropskiego, jak i Magdaleny Gilickiej. Ten pierwszy autor dowodzi, że ,nie byłoby poprawne, aby scharakteryzować Blausteina jako fenomenologa"15, ponieważ „był skrajnie sceptyczny wobec Husserlowskiego projektu fenomenologii"16. Z kolei ta druga autorka, śledząc wybrane elementy Blausteina krytyki fenomenologii, zarzuca polskiemu filozofowi „niewierność” oryginalnym terminom Husserla ${ }^{17}$. Obie oceny wydają się sugerować, że o byciu fenomenologiem decyduje bezkrytyczne podążanie za Husserlem. Z faktu, że Blaustein przygotował rozprawę doktorską na temat filozofii Badań logicznych i studiował u autora tej pracy we Fryburgu Bryzgowijskim, nie wynika, że był jego uczniem lub epigonem, co zresztą podkreśla Rosińska w swoim opracowaniu ${ }^{18}$. Co więcej, jak twierdził sam Blaustein we wspomnieniach o Twardowskim opublikowanych po śmierci założyciela SLW, filozofia jest wtedy wartościowa, gdy prowokuje do autokrytycyzmu, a nie jest jedynie ślepym podążaniem za mirażami ,nowej, jedynie zbawczej metody, która pozwoli im [studentom - W.P.] wreszcie rozwiązać odwieczne niemal, niepokojace ludzkość problemy filozoficzne"19. Komentarz ten można także odnieść do Husserla: w fenomenologii nie idzie tyle o powtarzanie tez

${ }^{13}$ Z. Rosińska włącza tę filozofię, jak pisze, do „tradycji fenomenologiczno-analitycznej”. Zob. eadem, Blaustein. Koncepcja odbioru mediów, Warszawa 2001, s. 56. W innej pracy Rosińska pisze: „I choć niewątpliwie obecność myśli Husserla jest widoczna w jego [Blausteina - W.P.] pracach, pozostał uczniem Kazimierza Twardowskiego. Mam tu na myśli ukształtowany styl filozofowania [...]. I choć może to brzmieć ryzykownie, [...] sposób jej [tj. filozofii Blausteina - W.P.] uprawiania nazwałabym fenomenologią analityczną"; eadem, Leopold Blaustein — styk psychologii i estetyki, [w:] L. Blaustein, Wybór pism estetycznych, s. X.

${ }^{14}$ W. Chudy, Zagadnienie naoczności aktów poznawczych, „Roczniki Filozoficzne” 29 (1981), nr 1, s. 185 .

15 M. Pokropski, op. cit., s. 94.

16 Ibidem.

17 Według Gilickiej: „Minusem rozprawy jest pewnego rodzaju »niewierność« oryginalnym terminom Husserla, co może powodować wieloznaczności interpretacyjne, a tym samym być mylące zwłaszcza dla osób mało zaznajomionych z fenomenologią,. M. Gilicka, Leopolda Blausteina krytyka fenomenologii, „Folia Philosophica” 38 (2017), s. 113.

18 „Pracę doktorską pisał na temat poglądów Husserla. Z tego też powodu studiował u niego jeden semestr we Fryburgu Bryzgowijskim. Nie można jednak powiedzieć, że był uczniem Husserla". Z. Rosińska, Leopold Blaustein — styk psychologii i estetyki, s. X.

${ }^{19}$ L. Blaustein, Kazimierz Twardowski i jego uczniowie, „Przegląd Współczesny” 18 (1939), nr 69, s. 125 . 
jej założyciela, co o krytyczne wykorzystanie jej narzędzi ${ }^{20}$. Podobna postawa nie jest zresztą szczególna dla przypadku Blausteina, bo — jak trafnie zauważył Paul Ricoeur $^{21}$ — w zasadzie cała historia ruchu fenomenologicznego jest historia „herezji" wobec myśli Husserla. Niezależnie od tego, stajemy przed pytaniem o specyfikę metody stosowanej przez Blausteina.

\section{Elementy biografii intelektualnej Blausteina i dalsze wpływy na jego koncepcję}

Prace filozoficzne polskiego filozofa mają charakter przede wszystkim przedmiotowych analiz konkretnych zjawisk psychicznych, dajmy na to przeżyć podczas oglądania filmu w kinie lub podczas słuchaniu słuchowiska radiowego. Wzmianki o metodzie najczęściej pozostają w tle rozważań, ale konkretne analizy Blaustein prawie zawsze poprzedza chociaż krótkimi uwagami metodologicznymi ${ }^{22}$. Chcąc uchwycić to, w jaki sposób rozumie on stosowaną przez siebie metodę, adekwatne wydaje się także sięgnięcie do podejmowanych przez niego dyskusji i krytycznych ocen danych propozycji teoretycznych ${ }^{23}$. Do kogo jednak odwołuje się Blaustein i kto ukształtował jego koncepcję filozofii? Pewnych wskazówek dla określenia ram interpretacyjnych dla analizy metody fenomenologicznej przez Blausteina dostarcza jego biografia intelektualna.

Urodzony w 1905 roku Blaustein studiował filozofię i germanistykę na Uniwersytecie Jana Kazimierza we Lwowie prawdopodobnie w latach 1923-1927. Tam uczęszczał na wykłady z logiki (w latach 1924-1925), które prowadził Kazimierz Ajdukiewicz oraz (od 1925 roku) na zajęcia — wówczas jeszcze luźno związanego z uniwersytetem, chociaż podejmującego starania o profesurę — Romana Ingardena ${ }^{24}$. Nie ulega jednak wątpliwości, że nie tylko podczas studiów, lecz także później

${ }^{20}$ Rację ma zatem Krzysztof Wieczorek, dowodząc, że: ,Z [...] deklaracji [Blausteina — W.P.] jasno wynika, że w analizowanych przez siebie tekstach Husserla autor publikacji poszukuje narzędzi badawczych oraz inspiracji dla własnych dalszych badań, zmierzających w ściśle określonym i samodzielnie wyznaczonym kierunku; nie zamierza więc być wiernym, ortodoksyjnym głosicielem ani kontynuatorem idei Husserla, lecz odkrywcą nowych obszarów problemowych i nowych zastosowań tych metod oraz terminów fenomenologicznych, które okażą się akceptowalne i użyteczne we własnej pracy analitycznej”. K. Wieczorek, Leopolda Blausteina interpretacja świata zjawiskowego, „Studia z Filozofii Polskiej” 1 (2006), s. 156.

${ }^{21}$ Zob. P. Ricoeur, A l'école de la phénoménologie, Paris 1987, s. 9.

22 „Podczas lektury prac Blausteina uderza świadomość metodologiczna tego uczonego oraz kartezjańska dbałość - charakterystyczna także dla Twardowskiego i jego uczniów — o ukazywanie stosownej metody badawczej. [...] Każdy etap pracy jest poprzedzony metodyczną informacją, co i w jakim celu będzie czynione". Z. Rosińska, Blaustein. Koncepcja odbioru mediów, s. 61.

${ }^{23}$ Podobny zabieg podąża za wskazówką Rosińskiej, która w odniesieniu do filozofii Blausteina podkreśla: „Elementy metody badawczej odsłania się dobrze w polemice filozoficznej”. Z. Rosińska, Leopold Blaustein — styk psychologii i estetyki, s. X.

${ }^{24} \mathrm{O}$ staraniach Ingardena o katedrę na Uniwersytecie Kazimierza Wielkiego we Lwowie zob. R. Ingarden, Dzieje mojej „kariery uniwersyteckiej”, „Kwartalnik Filozoficzny” 27 (1999), nr 2, s. 183-201; oraz R. Jadczak, Wokót wniosku o profesure dla Romana Ingardena we Lwowie, „Ruch Filozoficzny” 51 (1994), nr 3-4, s. 268-274; i idem, Koleje starań o profesure dla Romana Ingardena, „Kwartalnik Filozoficzny" 27 (1999), nr 2, s. 229-242. 
największy wpływ miał na niego Twardowski, do którego, zarówno jako do osoby, jak i do jego filozofii, zawsze odnosił się z wielkim szacunkiem i uznaniem ${ }^{25}$. Pod kierunkiem Twardowskiego przygotował rozprawę doktorską, którą po niezbędnych uzupełnieniach i opracowaniu opublikowano w 1928 roku. Książka ta, pod tytułem Husserlowska nauka o akcie, treści i przedmiocie przedstawienia, była pierwszą napisaną w języku polskim monografią w całości poświęconą fenomenologii Husserla ${ }^{26}$. Można przypuszczać, że pod wpływem Twardowskiego Blaustein wyróżniał metodę fenomenologii przedstawioną przez Husserla w pierwszym wydaniu Badań logicznych z 1900 i 1901 roku. Fenomenologię rozumie się tam w duchu Fraza Brentana, nauczyciela Husserla i Twardowskiego w Wiedniu, jako formę psychologii opisowej. W latach dwudziestych XX wieku psychologia opisowa lata świetności miała już jednak za sobą, ustępując miejsca zyskującej na popularności psychologii postaci. Tak wyraźne nawiązanie do psychologii opisowej może zaskakiwać tym bardziej, że jeszcze przed publikacją doktoratu Blaustein studiował we Fryburgu Bryzgowijskim pod kierunkiem Husserla w semestrze letnim 1925 roku, a więc wtedy, gdy ten już dawno zarzucił projekt z Badań. W tym czasie Husserl prowadził wykłady Einleitung in die phänomenologische Psychologie oraz seminarium Übungen in der Analyse und Deskription rein geistiger Akte und Deskription rein geistiger Akte und Gebilde ${ }^{27}$. Pracował wówczas nad podstawami psychologii fenomenologicznej, która nie powielałaby błędów psychologii opisowej. Blaustein uczestniczył w tych zajęciach i, jak wspomina, miał wiele okazji do bezpośredniego kontaktu z Husserlem, dyskutując z nim nie tylko nad szczegółami metody fenomenologicznej, ale i nad ogólnym pojęciu filozofii oraz o zadaniach filozofa ${ }^{28}$. Fakt ten skłania do pytania o związki projektu polskiego filozofa z psychologia fenomenologiczną opracowaną w wykładach z 1925 roku oraz o ewentualne zapożyczenia z tego projektu w pracach nad psychologią opisową. W każdym razie z wymiany epistolarnej Husserla z Ingardenem ${ }^{29}$, a także Ingardena z Twardowskim wiemy ${ }^{30}$, że niemiecki filozof dobrze wspominał Blausteina. Wiemy także, że obaj korespondowali z sobą ${ }^{31}$, chociaż korespondencja ta się nie zachowała. W biblioteczce Husserla znajduje się także doktorat Blausteina z jego odręczną dedykacją.

${ }^{25}$ Zob. R. Jadczak, Uczeń i nauczyciel: Z listów Leopolda Blausteina do Kazimierza Twardowskiego z lat 1927-1930, [w:] ... a Mądrości zło nie przemoże, J.J. Jadacki, B. Markiewicz (red.), Warszawa 1993, s. $19-27$.

${ }^{26}$ Na temat rozwoju wczesnej fenomenologii w Polsce i miejsca Blausteina w tym tle zob. W. Płotka, Early Phenomenology in Poland (1895-1945): Origins, Development, and Breakdown, ,Studies in East European Thought" 69 (2017), nr 1, s. 79-91.

${ }^{27}$ Zob. K. Schuhmann, Husserl-Chronik. Denk- und Lebensweg Edmund Husserls, Den Haag 1977, s. $289-290$.

${ }^{28}$ Zob. L. Blaustein, Edmund Husserl i jego fenomenologia.

${ }^{29}$ Zob. E. Husserl, Briefwechsel. Bd. III. Die Göttinger Schule, in Verbindung mit E. Schuhmann, K. Schuhmann (red.), Dordrecht 1994, s. 226, 228, 232.

${ }^{30}$ Zob. R. Ingarden, Korespondencja Romana Witolda Ingardena z Kazimierzem Twardowskim, R. Kuliniak, D. Leszczyna, M. Pandura (red.), Kęty 2016, s. 351.

31 Wspomina o tym w swoich dziennikach Twardowski, notując 8 stycznia 1929 roku, że Blaustein pokazał mu kartkę od Husserl, w której dziękował za przysłanie swojego doktoratu. Zob. K. Twardowski, Dzienniki. Część II 1928-1936, R. Jadczak (red.), Warszawa 1997, s. 50. 
Pracując nad edycją swojego doktoratu Blaustein, przebywał w latach 1927-1928 na stypendium w Berlinie, gdzie nawiązał kontakty naukowe z tamtejszymi filozofami i psychologami. Pobyt ten, jak się wydaje, stanowi trzeci, oprócz studiów we Lwowie i Fryburgu Bryzgowijskim, istotny etap kształtowania się jego filozofii. W tym czasie słuchał wykładów Carla Stumpfa, z którym wcześniej, jeszcze w 1892 roku w Monachium, przyjaźnił się Twardowski ${ }^{32}$. Blaustein cenił nie tylko sposób prowadzenia wykładu przez Stumpfa, lecz także jego oryginalną myśl, przede wszystkim, co ważne, w zakresie psychologii ${ }^{33}$. Innym ważnym odniesieniem dla Blausteina była koncepcja psychologii opisowej i humanistycznej Wilhelma Dilthey, z którą zapoznał się w Berlinie podczas wykładów jego ucznia Eduarda Sprangera ${ }^{34}$. W latach trzydziestych istotnym punktem odniesienia dla odczytania fenomenologii Husserla przez Blausteina była permanentna dyskusja z Ingardenem, który uzyskał profesurę we Lwowie w 1933 roku i prowadził wykłady oraz seminaria skupiające relatywnie szeroką grupę studentów i badaczy zainteresowanych fenomenologią ${ }^{35}$. Wówczas także Blaustein coraz częściej nie zajmował się tyle teoretycznymi podstawami fenomenologii i psychologii opisowej, co raczej stosował te metody do analizy konkretnych zjawisk, czy to w filozofii sztuki, mediów, czy też edukacji. Nie otrzymując stanowiska na uniwersytecie, pracował w szkołach średnich we Lwowie i kontynuował swoje badania. Wiele miejsca poświęcał dociekaniom z estetyki ${ }^{36}$. Podsumowaniem tych prac miała być dłuższa rozprawa napisana przez Blausteina w języku niemieckim Die ästhetische Perzeption, którą ukończył w 1939 roku. Niestety jej rękopis zaginął w czasie drugiej wojny światowej ${ }^{37}$. Blaustein zginął razem z żoną i ich synem prawdopodobnie w getcie żydowskim we Lwowie w 1942 lub 1944 roku $^{38}$.

Podsumowując tę część artykułu, widzimy, że swoją koncepcję filozofii Blausteina budował na polemice z różnymi, należacymi do odmiennych tradycji, propozycjami filozoficznymi. Najważniejszymi punktami odniesienia byli dla niego, poza Husserlem i Twardowskim, Stumpf, Dilthey oraz Ingarden. Wpływy te można, jak się wydaje, podzielić na dwie ogólniejsze grupy: myślicieli rozwijających i nawiązujących do projektu psychologii opisowej (Twardowski, Dilthey, Stumpf) oraz do fenomenologii (Husserl). Zaznaczmy, że zaproponowany podział zasadniczo pokrywa

${ }^{32}$ Zob. K. Twardowski, Autobiografia filozoficzna, „Przegląd Filozoficzny — Nowa Seria” 1 (1992), nr 1 , s. 25 .

${ }^{33}$ Zob. L. Blaustein, Karl Stumpf, „Polskie Archiwum Psychologii” 10 (1937-1938), nr 1-4, s. 33-34.

${ }^{34}$ Zob. L. Blaustein, O zadaniach psychologii humanistycznej, „Przegląd Filozoficzny” 38 (1935), nr $1-2$, s. $33-57$.

${ }^{35}$ Ingarden wspomina, że od 1925 roku, gdy spotkał Blausteina po raz pierwszy na prowadzonych przez siebie zajęciach we Lwowie, ,prawie codziennie” z nim dyskutował. Po ukończeniu studiów przez Blausteina kontynuowali współpracę nie tylko przy okazji prywatnych spotkań, ale też na gruncie Polskiego Towarzystwa Filozoficznego lub na konwersatorium estetycznym, które Ingarden prowadził na uniwersytecie w latach 1934-1939. Zob. R. Ingarden, Leopold Blaustein - teoretyk radia $i$ filmu, „Zeszyty Prasoznawcze” 4 (1963), nr 3, s. 87.

${ }^{36}$ Zob. np. L. Blaustein, Wybór pism estetycznych.

${ }^{37}$ Zob. R. Ingarden, Leopold Blaustein - teoretyk radia i filmu, s. 87; oraz M.A. Dąbrowski, Bibliografia prac Leopolda Blausteina, s. 245.

${ }^{38}$ Zob. J.J. Jadacki, Życiorysy niedokończone, [w:] ... a Madrości zło nie przemoże, s. 161; Z. Rosińska, Blaustein. Koncepcja odbioru mediów, s. 16; eadem, Leopold Blaustein — styk psychologii i estetyki, s. IX. 
się z propozycją Chudego, który pisze o „podwójnym pniu” koncepcji Blausteina ${ }^{39}$, przy czym obraz ten zostaje skomplikowany przez dodanie tradycji wywodzaccych się od Diltheya i Stumpfa.

\section{Wpływy i nawiązania do psychologii opisowej (Twardowski, Dilthey, Stumpf)}

Psychologia opisowa była jednym z najważniejszych kierunków badawczych w filozofii drugiej połowy XIX wieku i początku XX wieku przede wszystkim dzięki pismom i działalności dydaktycznej Brentana, którego uczniowie mieli olbrzymi wpływ na rozwój filozofii tamtego okresu. Wystarczy wspomnieć w tym kontekście o Husserlu, Stumpfie, Antonie Martym, Alexiusie Meinongu czy też o Christianie Freiherra von Ehrenfelsie ${ }^{40}$. W Polsce projekt Brentana zyskał na popularności dzięki Twardowskiemu, który studiował w Wiedniu w latach 1886-1895. Analizując wpływy Brentana na Twardowskiego i SLW, często podkreśla się nawiązania na gruncie logiki, metodologii i metafilozofii ${ }^{41}$. W tej części artykułu chciałbym bliżej przyjrzeć się wątkowi psychologicznemu w SLW oraz określić jego obecność w projekcie filozoficznym Blausteina. W tym celu sięgnę nie tylko do rozważań Twardowskiego, lecz także Diltheya oraz Stumpfa.

Teresa Rzepa definiuje trzy okresy kształtowania się psychologii w SLW: pierwszy okres rozpoczyna się objęciem katedry przez Twardowskiego we Lwowie (1895) i kończy pierwszą obroną doktoratu z zakresu psychologii (w 1901 roku) przez Władysława Witwickiego; drugi okres obejmuje lata 1902-1919 i jest to okres rozwoju psychologii lwowskiej, jak pisze Rzepa, „wyraźnie zorganizowanej wokół psychologicznych poglądów Twardowskiego. Specyficznym rysem tego okresu jest praca Mistrza i uczniów nad ustaleniem polskiej terminologii psychologicznej"42; trzeci okres to lata 1920-1939, gdy uczniowie Twardowskiego tworzą oryginalne projekty psychologiczne, rozwijając, także polemicznie, idee Mistrza; w tym okresie członkowie SLW obejmuja katedry poza Lwowem, na przykład Stefan Błachowski i Ludwik Jaxa-Bykowski zostają profesorami psychologii w Poznaniu już w 1919 roku ${ }^{43}$. Rzepa włącza myśl Blausteina do trzeciego okresu ${ }^{44}$. Co ważne, nie tylko polemizował on z Twardowskim, ale i nawiązywał do wielu elementów projektu, który założyciel SLW sukcesywnie rozwijał od pierwszych omówień po przybyciu do Lwowa.

\footnotetext{
39 Zob. W. Chudy, op. cit., s. 185.

${ }^{40} \mathrm{O}$ wpływie Brentana na filozofię europejską zob. B. Smith, Austrian Philosophy. The Legacy of Franz Brentano, Chicago 1994.

${ }^{41} \mathrm{Na}$ ten temat zob. J. Woleński, Szkoła lwowsko-warszawska: między brentanizmem a pozytywizmem, „Principia” 8-9 (1994), s. 83: idem, Brentanian Motives in Kazimierz Twardowski and His Students, [w:] The Significance of the Lvov-Warsaw School in the European Culture, A. Brożek, F. Stadler, E. Woleński (red.), Dordrecht 2017, s. 47-64.

42 T. Rzepa, Psychologia w szkole lwowsko-warszawskiej, „Przegląd Filozoficzny — Nowa Seria” 1 (1992), nr 1, s. 37.

${ }^{43}$ Zob. J. Woleński, Filozoficzna szkoła lwowsko-warszawska, Warszawa 1985, s. 20.

44 Zob. T. Rzepa, Psychologia w szkole lwowsko-warszawskiej, s. 38.
} 
Warto podkreślić, że Twardowski modyfikował swój projekt psychologii opisowej, początkowo pozostając pod wyraźnym wpływem Brentana, aby ostatecznie, w latach 1910-1913 wprowadzić istotne zmiany. We wczesnej pracy Psychologia wobec fizjologii i filozofii (1897) znajdujemy typowo Brentanowską tezę, że to „Psychologia [...] dostarcza filozofii nie tylko metody, lecz także przedmiotu" ${ }^{\prime 4}$. Twardowski, w duchu Brentana $^{46}$, oskarża Comte'a, że ten w sposób nieuzasadniony odrzuca możliwość zarazem introspekcji, jak i obserwacji wewnętrznej ${ }^{47}$. Zdaniem polskiego filozofa Comte ma rację, gdy przeczy możliwości obserwacji, bo nie jest możliwe uważne śledzenie własnych przeżyć, ale myli się co do introspekcji. Metoda introspekcyjna polega na wewnętrznym doświadczaniu przeżyć i Twardowski opisuje ją jako „wgląd w siebie”. Innymi słowy, metoda ta umożliwia bezpośrednie poznanie tego, co się wewnętrznie przeżywa, a tym samym umożliwia dalsze kroki analizy: opis i klasyfikację. Tutaj metoda determinuje przedmiot, którym są przeżycia lub zjawiska psychiczne. Introspekcja ma jednak pewne braki, ponieważ nie tylko ogranicza pole badawcze do przeżyć podmiotu, ale i umożliwia odnotowanie jedynie momentalnych przeżyć, które wraz z samym odnotowaniem przemijają. Z tego powodu psychologia powinna się wspierać innymi metodami. Twardowski wskazuje w tym kontekście na dwie metody: metodę retrospekcyjną oraz metodę eksperymentalną ${ }^{48}$. Pierwsza polega na zatrzymywaniu przeżyć w pamięci, druga zaś na wywoływaniu określonych przeżyć w sobie przez psychologa lub, jeżeli to nie jest możliwe, na analizie ankiet, będących raportami innych podmiotów, którzy przeżywają określone, niedostępne psychologowi w introspekcji doświadczenia (na przykład daltonizm). Jak widzimy, wczesne stanowisko Twardowskie łączy w sobie psychologizm metodologiczny (metoda psychologii jest także metodą filozofii) z psychologizmem ontologicznym (przedmiot jest zredukowany do przeżyć $)^{49}$. Niezależnie od tego, warto zaznaczyć, że tym, co Blaustein czerpie z tej pierwszej ekspozycji psychologii opisowej to wyróżnienie metod introspekcyjnych i retrospekcyjnych ${ }^{50}$ oraz, co nie mniej ważne, akceptację eksperymentu w badaniach psychologicznych. Jak pisał w Przedstawieniach imaginatycznych (1930):

Psychologii deskryptywnej nie przeciwstawiam eksperymentalnej [...]. Opis i eksperyment są dwiema metodami jednej i tej samej nauki. Nie wyklucza to, iż wśród przedmiotów badań psychologicznych istnieją dziedziny dostępne bądź to metodzie opisowej, bądź to tylko eksperymentalnej. W przeważnej może jednak części opis i eksperyment są dwiema frazami badań psychologicznych. Eksperyment niekiedy weryfikuje rezultaty psychologii deskryptywnej, zazwyczaj jednak bada swoiste zagadnienia, opierając się na podstawowych pojęciach, zanalizowanych i określonych w ramach psychologii deskryptywnej $^{51}$.

${ }^{45}$ K. Twardowski, Wybrane pisma filozoficzne, Warszawa 1965, s. 109.

${ }^{46}$ Zob. F. Brentano, Psychologia z empirycznego punktu widzenia, tłum. wstęp i przypisy W. Galewicz, Warszawa 1999, s. 46-50.

${ }^{47} \mathrm{~K}$. Twardowski, Wybrane pisma filozoficzne, s. 96-99.

48 Zob. ibidem, s. 100-101.

${ }^{49} \mathrm{~W}$ sprawie dyskusji nad tezą, czy u wczesnego Brentana rzeczywiście mamy do czynienia z psychologizmem, czy raczej jego teorię można także interpretować jako antypsychologistyczną zob.

A. Chrudzimski, Intentionalitätstheorie beim frühen Brentano, Dordrecht 2001, s. 33-37.

${ }^{50}$ Zob. L. Blaustein, W sprawie wyobrażen imaginatywnych, „Przegląd Filozoficzny” 34 (1931), nr 2-3, s. 183.

${ }^{51}$ L. Blaustein, Wybór pism estetycznych, s. 40, przypis 1. 
W 1911 roku Twardowski opublikował ważny artykuł o Czynnościach $i$ wytworach, w którym wyraźnie oddziela od siebie proces i rezultat lub wytwór tej czynności. W tym samym czasie polski filozof korzysta z tego odróżnienia na gruncie psychologii, co umożliwia mu przekroczenie niektórych ograniczeń wczesnego Brentanowskiego projektu psychologii opisowej ${ }^{52}$. W tym kontekście przygotowuje do druku dwie ważne prace: O metodzie psychologii. Przyczynek do metodologii badań naukowych (1910) i (opracowany jako hasło encyklopedyczne) O psychologii, jej przedmiocie, zadaniach, metodzie, stosunku do innych nauk $i$ o jej rozwoju (1913). W obu tych tekstach znajdujemy wiele wątków, które łączą Twardowskiego z Brentaną: 1 . wciąż wyróżnia się metodę introspekcji ${ }^{53} ; 2$ introspekcję dalej rozumie się jako wewnętrzne spostrzeżenie i przeciwstawia się złożonemu aktowi obserwacji ${ }^{54}$; 3. dlatego odrzuca się możliwość obserwacji stanów psychicznych ${ }^{55} ; 4$. Twardowski nie rezygnuje także z możliwości metod retrospekcyjnych i eksperymentów introspekcyjnych $^{56}$; 5 . podobnie jak Brentano ${ }^{57}$, twórca SLW przyjmuje, że psychologia opisowa i eksperymentalna mogą wspierać i motywować swoje badania ${ }^{58}$; 6 . przeżycia psychiczne ujmuje się jako całości, które składają się z niesamodzielnych części ${ }^{59}$; w końcu 7. ogólnym celem psychologii jest klasyfikacja przeżyć życia psychicznego ${ }^{60}$.

W obu tekstach zarysowują się jednak wyraźne różnice. Zwróćmy uwagę na dwie. I tak, przyjmując ustalenia z pracy o Czynnościach $i$ wytworach, Twardowski rozszerza pole badawcze z jedynie funkcji psychicznych również na wytwory psychiczne $^{61}$. Funkcją psychiczną są takie akty, jak „postrzeganie” czy „mniemanie”, wytworem jest zaś odpowiednio „spostrzeżenie” i „przeświadczenie”. Wytworem mogą być także zapisane słowa. W tym kontekście psycholog może badać hipotetyczne stany mentalne (rozumiane jako funkcje), które doprowadziły do powstania danego produktu (na przykład utworu literackiego). Metoda ta, nazywana metodą interpretacji ${ }^{62}$, znaczacco rozszerza metodę introspekcyjną Brentana, bo

${ }^{52}$ Zob. np. J. Bobryk, The Genesis and History of Twardowski's Theory of Actions and Products, [w:] The Golden Age of Polish Philosophy. Kazimierz Twardowski's Philosophical Legacy, s. 33-42.

${ }^{53}$ Zob. K. Twardowski, Wybrane pisma filozoficzne, s. 208, 215, 256-257.

${ }^{54}$ Zob. ibidem, s. 209.

55 Zob. ibidem, s. 209, 261.

${ }^{56}$ Zob. ibidem, s. 210.

57 Zob. F. Brentano, Deskriptive Psychologie, Hamburg 1982, s. 8.

58 Zob. K. Twardowski, Wybrane pisma filozoficzne, s. 255-256.

${ }^{59}$ Zob. ibidem, s. 244.

${ }^{60}$ Zob. ibidem, s. 250.

${ }^{61}$ Zob. ibidem, s. 243.

${ }^{62}$ Rzepa charakteryzuje tę metodę następująco: „Kluczowe dla tej metody jest gromadzenie i badanie wszelkich wytworów ludzkich jako objawów życia psychicznego. Zebrane wytwory poddaje psycholog interpretacji psychologicznej. Intepretując wytwory, niejako przygląda się z pewnego czasowego dystansu danym zjawiskom psychicznym, których te wytwory mogą być objawami. Na tej podstawie wnioskuje o cudzym (również własnym) życiu psychicznym. [...] Zebrawszy odpowiednią »porcję《 informacji na temat danego zjawiska psychicznego na drodze psychologicznej interpretacji wytworów, psycholog formułuje prawa i pojęcia ogólne dla zakresu badanego zjawiska. Uzasadnia je logicznie. [...] Wreszcie, opatruje wieloma przykładami, tzn. uzupełnia ścisłymi i rzetelnie sporządzonymi protokołami zawierającymi opis danego zjawiska psychicznego". T. Rzepa, Psychologia w szkole lwowsko-warszawskiej, s. 41. 
umożliwia badanie tego, co nie jest bezpośrednio przeżywane. Oprócz metody interpretacji Twardowski dalej posługuje się metodą introspekcyjną, która polega na analizie przeżyć jako pewnych typów, nie zaś konkretnych przeżyćc3. Co jest jednak ważniejsze, odróżniając funkcje od wytworów z jednej strony oraz kierując badania na typy przeżyć, Twardowski odrzuca zarazem psychologizm ontologiczny, ponieważ inny status ma samo przeżycie (funkcja psychiczna), a inny wytwór tego przeżycia ${ }^{64}$. Wydaje się, że właśnie antypsychologizm (na gruncie ontologii przeżyć) jest tym elementem, który przejmuje Blaustein w swojej koncepcji, gdy podkreśla, że „fenomenologia jest możliwa tylko jako empiryczna, deskryptywna nauka o typach (najniższych gatunkach) przeżyć czystej świadomości, a nie jako aprioryczna deskryptywna nauka o wyższych istotach jako idealnych przedmiotach"65. W fenomenologii, którą polski filozof proponuje rozumieć na wzór psychologii opisowej, filozof docieka typów przeżyć, nie zaś konkretnych doświadczeń. Dzięki temu przedmiot nie jest zredukowany do przeżycia (jak w psychologizmie ontologicznym), lecz zachowuje odrębność i ogólność.

Jak się wydaje, Blaustein, definiując przedmiot psychologii jako życie psychiczne, mógł nawiązywać nie tylko do Twardowskiego, lecz także do Diltheya. W pracy Ideen über eine beschreibende und zergliedernde Psychologie (1894) filozof ten przeciwstawia sobie psychologię wyjaśniającą opisujacej. Ta pierwsza przyjmuje w swoim postępowaniu różne hipotezy o naturze życia psychicznego, dajmy na to, istnienie wrażeń i poprzez włączenie ich w ciągi przyczynowo-skutkowe stara się wyjaśnić dane zjawisko ${ }^{66}$. Z kolei psychologia opisowa prezentuje elementy i zależności różnych form życia psychicznego, przy czym elementy te nie są wydedukowane lub dodane, lecz konkretnie i żywo przeżywane oraz doświadczane (erlebt $)^{67}$. Metoda ta również opiera się na doświadczeniu wewnętrznym i dąży, jak trafnie

${ }^{63}$ Rzepa twierdzi, że metoda ta, nazywana przez nią „,analityczną”, zawiera cztery kroki: „,(a) poszukuje się na niewielu prostych przykładach definicji analitycznych; (b) przez te definicje analityczne definiuje się badane przedmioty; ale nie jako zjawiska konkretne, lecz jako pewien typ; (c) na podstawie tych definicji formułuje się twierdzenia analityczne, po czym (d) stwierdzenia te sprawdza się w praktyce”. T. Rzepa, Psychologiczne poglady Kazimierza Twardowskiego, „Studia Philosophiae Christianae” 27 (1991), nr 2, s. 171.

${ }^{64} \mathrm{Na}$ marginesie warto zaznaczyć, że sam Twardowski uważał, że psychologizm odrzucił on już w 1903 roku, gdy twierdził, że „Należy bronić logikę przed psychologizmem, gdyż na tej drodze łatwo dojść do sceptycyzmu". K. Twardowski, Ankieta w sprawie nauczania propedeutyki filozoficznej w gimnazjach, „Przegląd Filozoficzny” 6 (1903), nr 1, s. 113.

${ }^{65}$ L. Blaustein, Próba krytycznej oceny fenomenologii, „Ruch Filozoficzny” 11 (1928-1929), s. 165 b.

${ }^{66}$ Zob. W. Dilthey, Ideen über eine beschreibende und zergliedernde Psychologie, [w:] idem, Gesammelte Schriften, cz. 5. Die Geistige Welt. Einleitung in die Philosophie des Lebens, Erste Hälfte, Leipzig-Berlin 1924, s. 140.

67 „Ich verstehe unter beschreibender Psychologie die Darstellung der in jedem entwickelten menschlichen Seelenleben gleichförmig auftretenden Bestandtheile und Zusammenhänge, wie sie in einem einzigen Zusammenhang verbunden sind, der nicht hinzugedacht oder erschlossen, sondern erlebt ist. Diese Psychologie ist also Beschreibung und Analysis eines Zusammenhangs, welcher ursprünglich und immer als das Leben selbst gegeben ist. Hieraus ergiebt sich eine wichtige Folgerung. Sie hat die Regelmässigkeiten im Zusammenhange des entwickelten Seelenlebens zum Gegenstand. Sie stellt diesen Zusammenhang des inneren Lebens in einem typischen Menschen dar". Ibidem, s. 152. 
zauważa Wolfgang Röd, „do zrozumienia całościowego kontekstu świadomości”68. Chociaż, w przeciwieństwie do Twardowskiego, Dilthey nie odrzucał psychologizmu, przyjmując, że to psychologia jest nauką fundamentalną, silniej od polskiego filozofa podkreśla holistyczne ujęcie życia psychicznego. Oczywiście Twardowski posługuje się wyrażeniem ,życie psychiczne", pisząc o przedmiocie psychologii ${ }^{69}$, ale zaraz dodaje, że można je ująć jako złożenie faktów psychicznych. W przeciwieństwie do tego Dilthey konsekwentnie podkreśla, że związki, które budują życie psychiczne są niezrozumiałe poza całościowym kontekstem ${ }^{70}$. Blaustein nawiązuje do Diltheya, definiujacc przedmiot psychologii jako „pierwotnie naturalną całość psychologiczną", a więc właśnie jako konkretne życie psychiczne ${ }^{71}$. Nie chodzi przy tym o to, że życie psychiczne lub dane przeżycie jest całością (w sensie przedmiotu, który zawiera swoje części). Blaustein, idąc za Diltheyem, pokazuje, że całościowe ujęcie życia psychicznego wymaga włączenia do analizy innych obszarów, które kształtują to życie: sfery religijnej, politycznej itp. Psychologia taka jest nazywana „humanistyczną", ponieważ włącza człowieka w, jak pisze polski filozof, „obręb rzeczywistości humanistycznej"72.

Kolejnym filozofem, do którego nawiązywał Blaustein, a którego można włączyć do grupy psychologów opisowych, jest Stumpf. Filozof ten tworzył swoją koncepcję początkowo pod wpływem Brentana, później jednak polemizował z Husserlem, kreśląc odmienne od niego ujęcie fenomenologii ${ }^{73}$. Stumpf przejął od Brentana tezę, że psychologia jest podstawą nauk, w tym również nauk filozoficznych ${ }^{74}$, od Husserla zaś, że prawa aprioryczne są nieredukowane do przeżyć. Tym samym łączył psychologizm metodologiczny z antypsychologizmem ontologicznym. Z autorem Psychologii z empirycznego punktu widzenia dzielił tezę o dwóch rodzajach spostrzeżeń: zewnętrznych i wewnętrznych, ale inaczej niż on Stumpf uznawał obserwację (Beobachtung) życia wewnętrznego jako miarodajną metodę badań psychologicznego $^{75}$. Jego rozumienie psychologii i fenomenologii zostaje wyraźnie zarysowane w dwóch traktatach: Erscheinungen und psychische Funktionen oraz Zur Einteilung der Wissenschaften, które w 1906 roku niemiecki filozof przygotował dla Königlich-Preußischen Akademie der Wissenschaften. W pierwszej z tych prac Stumpf wskazuje na dwa rodzaje przedmiotów: 1. zjawiska (Erscheinungen),

${ }^{68}$ W. Röd, Wilhelm Dilthey a filozofia hermeneutyczna, „Studia Philosophica Wratislaviensia” 7 (2012), nr 1, s. 95.

${ }^{69}$ K. Twardowski, Wybrane pisma filozoficzne, s. 206.

70 Zob. W. Dilthey, op. cit., s. 144-148, 150-153, 156-158.

${ }^{71}$ Zob. L. Blaustein, O zadaniach psychologii humanistycznej, s. 36-38.

72 Zob. ibidem, s. 44.

${ }^{73}$ Zob. C. Stumpf, Carl Stumpf, [w:] Philosophie der Gegenwart in Selbstdarstellungen, Bd. 5, R. Schmidt (hrsg.), Leipzig 1924, s. 205-265. Przegląd dyskusji Stumpfa z Brentaną i Husserlem przedstawia D. Fisette, Stumpf and Husserl on Phenomenology and Descriptive Psychology, „Gestalt Theory” 31 (2009), nr 2, s. 175-190.

74 Tezę tę Stumpf sformułował w dyskusji z krytycyzmem Kanta, pokazujacc, że dociekania aprioryczne nie mają same przez się ważności przedmiotowej. Z tego powodu ,psychologische Untersuchungen für den Erkenntnistheoretiker unentbehrlich sind". C. Sumpf, Psychologie und Erkenntnistheorie, „Abhandlungen der Königlich Bayerischen Akademie der Wissenschaften” 19 (1891), nr 2, s. 490.

${ }^{75}$ C. Stumpf, Carl Stumpf, s. 243. 
które ujmuje się jako treści wrażeń zmysłowych (Inhalte der Sinnesempfindungen) i pomiędzy którymi zachodzą pewne związki (Verhältnisse); oraz 2. funkcje psychiczne, które opisuje się jako akty lub przeżycia, a które ujmują zjawiska w pewne złożenia, tworząc o nich pojęcia i powodując poruszenia woli ${ }^{76}$. Oba elementy są niesamodzielne wobec siebie i tworzą rzeczywistą jedność (reale Einheit), chociaż różnicę pomiędzy nimi można ująć opisowo, co świadczy o ich „relatywnej samodzielności".

W drugim ze wspomnianych wykładów Stumpf korzysta z tego odróżnienia i buduje na ich podstawie klasyfikację nauk, z których nas interesują dwie: psychologia opisowa bada funkcje psychiczne, a dokładniej elementarne funkcje psychiczne, zaś fenomenologia — zjawiska ${ }^{77}$. Tym samym Stumpf proponuje odmienne od Husserla rozumienie fenomenologii, która nie tyle bada wewnętrzne doświadczenie, czyli akty, ile raczej treść samych wrażeń ${ }^{78}$. W Ideach $I$ odnotowuje się tę różnicę, sugerując zarazem, że Stumpfowska fenomenologia może być zrównana z hyletyką, przy czym pełne utożsamienie nie jest możliwe ze względu na różnice metodologiczne: Husserl zajmuje stanowisko transcendentalne, podczas gdy Stumpf — psychologistyczne $^{79}$. Blaustein był świadom tych różnic pojęciowych i metodologicznych ${ }^{80}$. Wydaje się, że koncepcja zarysowana w dwóch wykładach z 1906 roku, która rezygnuje z roszczeń transcendentalnych, była bliska polskiemu filozofowi. Świadczą o tym dwie sprawy. Po pierwsze, Blaustein zdawał się akceptować to, że nie jest możliwa czysto aprioryczna psychologia, dlatego obserwacje i eksperymenty są konieczne; tak samo uważał Stumpf ${ }^{81}$. Po drugie, polski filozof już w swojej rozprawie doktorskiej, dyskutując z Husserla ujęciem świadomości i jej elementów, dowodził, że świat składa się z dwóch części: materialnej i zjawiskowej ${ }^{82}$; następnie, wrażenia przypisywał temu drugiemu światu. Samo wyrażenie ,świat zjawiskowy" zdaje się pochodzić wprost z filozofii Stumpfa, który pisze o „Erscheinungswelt" ${ }^{\prime 3}$; również zjawiska ujmuje się jako treści wrażeń i przypisuje tej zewnętrznej wobec psychiki warstwie świata. Argument ten Blaustein, jak się wydaje, wprost czerpie ze Stumpfa, chociaż polski filozof $\mathrm{w}$ tym fragmencie doktoratu nie odnosi się wprost do niego.

\footnotetext{
76 Zob. C. Stumpf, Erscheinungen und psychische Funktionen, Berlin 1906, s. 4-5.

77 Zob. C. Stumpf, Zur Einteilung der Wissenschaften, Berlin 1906, s. 21, 27.

78 Zob. ibidem, s. 35, przypis 2. C. Stumpf, Carl Stumpf, s. 40-41.

${ }^{79}$ Zob. E. Husserl, Idee czystej fenomenologii i fenomenologicznej filozofii, tłum. D. Gierulanka, Warszawa 1967, s. 296-297. Dalej cytowane jako Idee I.

${ }^{80}$ Zob. L. Blaustein, Karl Stumpf, s. 34; idem, Husserlowska nauka o akcie, treści i przedmiocie przedstawienia, s. 2, przypis 2 .

${ }^{81}$ Zob. C. Stumpf, Carl Stumpf, s. 214. Na ten temat, zob. także R. Martinelli, A Philosopher in the Lab. Carl Stumpf on Philosophy and Experimental Sciences, „Philosophia Scientiæ” 19 (2105), nr 3, s. 23-43. Z kolei przykłady wykorzystania metod eksperymentalnych i metody ankiet w psychologii u Blausteina zob. np. L. Blaustein, Psychologiczne podstawy oświaty pozaszkolnej, Warszawa 1935, s. 19; idem, Wpływ wychowawczy filmy, Lwów 1937, s. 6, 7-8, przypis 2, 10; idem, O percepcji słuchowiska radiowego, Warszawa 1938, s. 26, 43 .

${ }^{82}$ Zob. L. Blaustein, Husserlowska nauka o akcie, treści i przedmiocie przedstawienia, s. 74, 76-77.

${ }^{83}$ Zob. Zob. C. Stumpf, Erscheinungen und psychische Funktionen, s. 11.
} 


\section{Wpływy i nawiązania do fenomenologii (Husserl)}

Fenomenologia jest drugim, obok psychologii opisowej, „pniem”, z którego wyrasta filozofia Blausteina. Nawiązania do Husserla i Ingardena są trwałym elementem dzieł tego autora. Często mają one charakter polemiczny i służą zarysowaniu własnej, oryginalnej propozycji filozoficznej. Wydaje się jednak, że pomimo wyraźnego polemicznego, a nawet krytycznego wydźwięku odczytania Blausteina filozof ten czerpie przynajmniej z niektórych osiągnięć fenomenologii. Dlatego w tej części artykułu bliżej przyjrzę się krytyce fenomenologii, którą formułuje polski filozof, aby konfrontujacc ją z pracami Husserla, przede wszystkim z wykładem o psychologii fenomenologicznej z 1925 roku, wskazać możliwe zapożyczenia i nawiązania.

Najpełniejszej krytyki metody fenomenologicznej Blaustein dokonał przy okazji dwóch referatów wygłoszonych 28 kwietnia i 5 maja 1928 roku na posiedzeniach Polskiego Towarzystwa Filozoficznego ${ }^{84}$. Krytyka ta uderza przede wszystkim w niejasne rozumienie istoty jako przedmiotu ogólnego. Blaustein formułuje przy tym pięć różnych zarzutów i wątpliwości; pisze o sprawach logicznych (istota nie ma swojego realnego definiensu), epistemologicznych (nie da się w całości ująć istoty, lecz co najwyżej jako ,schemat”), ontologicznych (niejasny jest sposób ,istnienia” przedmiotów ogólnych) oraz psychologicznych (istota jest ostatecznie jedynie przedmiotem psychicznym) i metodologicznych (istnienie przedmiotów ogólnych zakłada się na początku, ale sprawę ich istnienia należy dopiero rozstrzygnaćć) ${ }^{85}$. Wątpliwości te, zdaniem Blausteina, świadczą o niemożliwości fenomenologii rozumianej jako ejdetyczna analiza czystej świadomości. Co najwyżej, fenomenologia jest możliwa jako „empiryczna, deskryptywna nauka o typach (najniższych gatunkach) przeżyć czystej świadomości, a nie jako aprioryczna deskryptywna nauka o wyższych istotach jako idealnych przedmiotach"86. Dzieje się tak, ponieważ podstawowa metoda fenomenologii, czyli ogląd ejdetyczny (Wesenschau) jest nieadekwatna. Zamiast badać konkretne przeżycia, metoda ta dotyczy istot, czyli tego, co ogólne, a co istnieje w ,świecie idei" (określenie Blausteina). Według polskiego filozofa, to nie idee kształtuja doświadczenie, lecz odwrotnie. Właśnie dlatego, konkluduje Blaustein, fenomenologia nie może być fundamentem innych nauk materialnych, chociaż w ograniczonym zakresie może dostarczyć naukom podstaw ontologii formalnej.

Zarzuty Blausteina są jednak nietrafione. Już bowiem w Badaniach logicznych Husserl buduje metodę analizy ejdetycznej w dyskusji z nowożytną teorią abstrakcji, jednoznacznie przeciwstawiając się hipostazowaniu idei jako przedmiotów ogólnych $^{87}$. To, co się ujmuje w ideacji to nie tyle przedmiot ogólny, ile moment danego przeżycia. Co więcej, w drugim wydaniu swojego działa z 1913 roku niemiecki filozof podkreśla, że fenomenologia nie jest psychologią opisową, ponieważ posłu-

${ }^{84}$ Zob. L. Blaustein, Próba krytycznej oceny fenomenologii.

85 Argumentację Blausteina można osadzić także w szerszym kontekście dyskusji nad rozumieniem fenomenologii w Polsce, przede wszystkim w kontekście sporu realizm-idealizm. Na ten temat zob. W. Płotka, Fenomenologia jako filozofia mniejsza. Rozważania wokót sporów o metodę Husserla, Warszawa 2019, s. 112-125.

${ }^{86}$ L. Blaustein, Próba krytycznej oceny fenomenologii, s. 165b.

${ }^{87}$ Zob. E. Husserl, Badania logiczne, t. 2. Badania dotyczace fenomenologii i teorii poznania, cz. 1, tłum., wstęp i przypisy J. Sidorek, przekład przejrzał A. Półtawski, Warszawa 2000, s. 151-152. 
guje się „czystym” opisem, który nie ma nic wspólnego z opisem empirycznym; tak przedefiniowana fenomenologia polega na ,wypatrzeniu” istoty na podstawie ,przykładowego uchwycenia naocznego jednostkowych przeżyć", a przez to na opisie tego, co ujęte ${ }^{88}$. Z kolei w Ideach $I$ wprowadza się zabieg redukcji, który zawiesza kwestię istnienia istoty. Ideę pojmuje się przy tym jako „Co” danego przedmiotu ${ }^{89}$. Ujęcie istoty ma charakter przedmiotowy, ale to, co dane w takim akcie, idąc za Husserlem, nie jest ujmowane jako istniejące (daseiend). Autor Idei I przeciwstawia się przy tym ,platońskiemu tworzeniu hipostaz"90, gdy ideę ujmuje się jako byt realny. Dla niego idea jest korelatem odpowiednich aktów, które rozumie jako źródłową prezentację istoty i opisuje jako akt źródłowo prezentujący; oczywiście, istota nie sprowadza się do tych aktów, lecz jest ich korelatem.

Widzimy zatem, że krytyka Blausteina ma ograniczony zasięg. Jeżeli jednak weźmie się pod uwagę wykłady Husserla o psychologii fenomenologicznej z 1925 roku, okazuje się, że polski filozof korzysta z pewnych ustaleń autora Idei I. Sięgnięcie do wykładów z 1925 roku jest uzasadnione tym, że Blaustein posługuje się w swoich polemikach terminem „Wesenschau”, które nie występuje ani w Badaniach logicznych, ani w Ideach I, lecz właśnie w tych wykładach; Blaustein miał okazję słuchać tych wykładów podczas pobytu w Niemczech. W każdym razie wykłady Husserla były poświęcone próbie fenomenologicznego ugruntowania psychologii i określeniu jej miejsca w kontekście nauk humanistycznych. Na samym początku autor analizuje wybrane formy psychologii końca XIX wieku, przeciwstawiajacc sobie psychologię „wyjaśniającą” i „opisowo-analityczną” w ujęciu Brentana i Diltheya. Ta pierwsza posługuje się procedurą konstrukcyjno-hipotetyczną, która polega na przyjmowaniu pewnych elementów, na przykład danych zmysłowych, następnie włączanych w związki przyczynowe. Ta druga zaś postępuje w sposób czysto intuitywny. W rezultacie krytycznego opracowania tych projektów Husserl dochodzi do wniosku, że „nowa psychologia” charakteryzuje się apriorycznością, nakierowaniem na eidos, intuicją lub czystym opisem oraz zainteresowaniem intencjonalnością ${ }^{91}$. Aby badanie takie było możliwe, w „Systematischer Teil' autor przybliża podstawowe elementy metody ejdetycznej. Pokazuje, że poszczególne jednostki oraz sam świat mają sobie właściwą formę, w której może pojawić się określona treść. Badanie tych form jest możliwe w czystej fantazji, w której ujmuje się a priori poprzez świadomość „tego, co niezmienne” w wolnym uwariowaniu doświadczenia ${ }^{92}$. W myśl tej teorii świat istot jest światem czystej fantazji, czyli światem czystych możliwości. Należy przy tym podkreślić, że eidos jest rozumiany bez ,interpretacji metafizycznych", co pozwala na ujęcie go jako czystego gatunku

88 Zob. ibidem, s. 24-25.

${ }^{89}$ Zob. Idee I, s. 20.

90 Zob. ibidem, s. 73.

91 Zob. E. Husserl, Phänomenologische Psychologie. Vorlesungen Sommersemester 1925, W. Biemel (red.), Husserliana: Edmund Husserl Gesammelte Werte, cz. 9, Den Haag 1968, s. 46-51.

${ }^{92} \mathrm{Na}$ temat tej metody zob. B.C. Hopkins, Phenomenological Cognition of the A Priori: Husserl's Method of „Seeing Essences” (Wesenserschauung), [w:] Husserl in Contemporary Context, B.C. Hopkins (red.), Dordrecht 1997, s. 151-178. 
(reine $A r t)^{93}$. W sensie dosłownym niczego się tutaj zatem nie „widzi”. Nie jest to „postrzeganie zmysłowe”, ponieważ wariacja w czystej fantazji jest dana w modi „, tak dalej”, a więc w sposób postępujących zmian i odnotowanych podobieństw. Mówienie tutaj o „oglądzie” odnosi się do świadomości, w której konstytuuje się nowy rodzaj przedmiotu, a mianowicie to, co uniwersalne.

Treść wykładów Husserla, przytoczona tutaj jedynie szkicowo, podważa krytykę Blausteina. Nietrafiony jest przede wszystkim główny zarzut, że Husserl ujmuje eide jako „przedmioty ogólne”, które istnieja w „świecie idei”. Co jest jednak ważniejsze, w swojej krytyce Blaustein przyjmuje wiele elementów metody opisanej przez Husserla czy też, formułując tę tezę w słabszej formie, metoda zaproponowana przez niego ma zaskakująco dużo elementów wspólnych z tą opisaną przez niemieckiego fenomenologa. Podobnie jak autor Idei I Blaustein podkreśla silny związek metody psychologicznej z doświadczeniem tego, co indywidualne. Oboje piszą także o typach i gatunkach dla wyjaśnienia statusu idei i przyjmują, że ogląd ejdetyczny nie ma charakteru dowodzenia aksjomatów, lecz co najwyżej służy ujęciu stanu rzeczy wyrażonego przez aksjomat. Idąc za Diltheyem, obaj filozofowie - Husserl i Blaustein - przeciwstawiają się także postępowaniu hipotetyczno-konstrukcyjnemu w opisach psychologicznych i ujmują życie psychiczne jako jedność przeżyć.

\section{Zakończenie}

Celem tego artykułu była próba określenia ram interpretacyjnych, w których można sytuować filozofię Blausteina. Realizacja tak postawionego zadania wypływa z potrzeby zmierzenia się z rozbieżnymi interpretacjami tej myśli. Blausteina ujmuje się bowiem raz jako ,sławnego fenomenologa"94, to znowu jako „quasi-fenomenologa"95. Aby zrealizować zakładany cel zaproponowałem tutaj przedstawienie metody badawczej tego filozofa, pytając zresztą o jej oryginalność. I tak w części pierwszej niniejszej pracy polemizowałem z jednostronnymi i redukcyjnymi ujęciami teorii Blausteina: czy to metody analizy logiczno-pojęciowej Twardowskiego, czy tė̇ do jedynie powtórzenia drogi myślowej Husserla. Analiza biografii intelektualnej polskiego filozofa — przedstawiona w części drugiej artykułu — pokazywała, że obraz ten nie jest adekwatny, bo pomija inne, mniej oczywiste źródła dla kształtowania się jego koncepcji. W ten sposób jako konieczne okazało się także uwzględnienie odniesień do Diltheya i Stumpfa.

Biorąc pod uwagę rezultaty obu części artykułu, w kolejnych dwóch analizowałem wybrane zapożyczenia i kontynuacje. W części trzeciej przybliżyłem wybrane elementy psychologii opisowej. Okazuje się, że Blaustein czerpał z tej tradycji przy określeniu przedmiotu analizy i elementów swojej metody. Przedmiot ten ujmował jako, życie psychiczne" (Twardowski, Dilthey), zaś metodę jako introspekcję i retrospekcję (Brentano, Twardowski), dzięki której analizuje się opisowo typy przeżyć (Twardowski). Badania muszą być jednak prowadzone w dwóch kierunkach, a mianowicie muszą

93 Zob. E. Husserl, Phänomenologische Psychologie, s. 74.

${ }^{94}$ Zob. M. van der Schaar, op. cit., s. 12.

${ }^{95}$ M. Pokropski, op. cit., s. 94. 
dotyczyć samych aktów, jak i wrażeń (Stumpf). W postępowaniu metodologicznym Blaustein nie wyłącza eksperymentów (Twardowski, Stumpf). Trudno jednak nazwać polskiego filozofa bezkrytycznym interpretatorem psychologii opisowej. Świadczy o tym chociażby to, że wbrew niektórym nurtom tej tradycji (wczesny Twardowski, Dilthey, Stumpf) nie akceptuje psychologizmu ontologicznego. W części czwartej artykułu skupiłem się na ujęciu przez Blausteina metody fenomenologicznej. Okazało się, że jego polemika ma ograniczony zasięg i odrębność obu stanowisk w zasadzie sprowadza się do odmiennej oceny wartości redukcji fenomenologicznej: o ile Husserl widzi w niej kamień węgielny fenomenologii, o tyle jego krytyk uważa, że zabieg ten prowadzi do hipostazowania pojęć. Dlatego Blaustein proponował rozwijanie fenomenologii nie jako apriorycznej ejdetyki, lecz jako empirycznej psychologii opisowej. Podobne ujęcie fenomenologii, jak pokazałem w tej części artykułu, nawiązuje do niektórych elementów projektu Husserla z 1925 roku. Psycholog opisowy w rozumieniu Blausteina analizuje bowiem zjawiska i życie psychiczne poprzez odnotowanie w opisie momentów doświadczenia i przez to metoda ta pozwala na przeżycie tego, co doświadczone jako doświadczone. Wydaje się, że ten ostatni element - ujęcie przedmiotu psychologii w określonym modus, czyli ,,jako" — stanowi o fenomenologicznym charakterze psychologii opisowej Blausteina. Co więcej, tym, co łączy projekt psychologii opisowej z fenomenologia jest brak zaufania do postępowania konstrukcyjno-hipotetycznego i wyróżnienie bezpośredniego doświadczenia.

W świetle dotychczasowych ustaleń można wyprowadzić wniosek, że w wypad$\mathrm{ku}$ metody stosowanej przez Blausteina mamy do czynienia z fenomenologicznie zorientowana psychologia opisowa, która jest pokrewna (z powodu odrzucenia redukcji), chociaż nie jest tożsama (z powodu uznania eksperymentów jako uzupełnienia opisów) z projektem przedstawionym przez Husserla w pierwszym wydaniu Badaniach logicznych i nawiązującym do wykładów niemieckiego filozofa z 1925 roku o psychologii fenomenologicznej. Tym samym nie powinno dziwić, że na początku swojej rozprawy doktorskiej polski filozof podkreślał, że „Fenomenolog [...] może w poniższych wywodach widzieć zastosowanie twierdzeń fenomenologicznych w psychologii deskryptywnej, psycholog deskryptywny — analizę, niezależną od jakiejkolwiek fenomenologii”"96. Można więc konkludować, że Blaustein na nowo odczytał psychologię opisową, sytuując ją w kontekście dalszych dyskusji nad jej przedmiotem i zakresem (na przykład Twardowski i Stumpf) oraz wykorzystujacc elementy projektu psychologii fenomenologicznej Husserla z 1925 roku.

\section{Bibliografia}

Blaustein L., Edmund Husserl $i$ jego fenomenologia, „Przegląd Humanistyczny” 5 (1930), nr 2, s 233-242; przedruk [w:] Polska fenomenologia przedwojenna. Antologia tekstów, D. Bęben, M. Ples-Bęben (red.), Katowice 2013, s. 223-233.

Blaustein L., Husserlowska nauka o akcie, treści i przedmiocie przedstawienia, Lwów 1928.

${ }^{96}$ L. Blaustein, Husserlowska nauka o akcie, treści i przedmiocie przedstawienia, s. 3. 
Blaustein L., Karl Stumpf, „Polskie Archiwum Psychologii” 10 (1937-1938), nr 1-4, s. $33-34$.

Blaustein L., Kazimierz Twardowski i jego uczniowie, „Przegląd Współczesny” 18 (1939), nr 69 , s. $124-129$.

Blaustein L., Kotarbiński Tadeusz. Elementy teorji poznania, logiki formalnej i metodologji nauk, Lwów Wyd. Zakt. Nar. im Ossolińskich 1929, s. VIII+483, „Przegląd Humanistyczny" 5 (1930), nr 4-5, s. 456-458.

Blaustein L., O percepcji stuchowiska radiowego, Warszawa 1938.

Blaustein L., O zadaniach psychologii humanistycznej, „Przegląd Filozoficzny” 38 (1935), nr 1-2, s. 33-57.

Blaustein L., Próba krytycznej oceny fenomenologii, „Ruch Filozoficzny” 11 (1928-1929), s. $164 \mathrm{~b}-166 \mathrm{~b}$.

Blaustein L., Psychologiczne podstawy oświaty pozaszkolnej, Warszawa 1935.

Blaustein L., W sprawie wyobrażeń imaginatywnych, „Przegląd Filozoficzny” 34 (1931), nr 2-3, s. 180-187.

Blaustein L., Wpływ wychowawczy filmy, Lwów 1937.

Blaustein L., Wybór pism estetycznych, Z. Rosińska (red.), Kraków 2005.

Bobryk J., The Genesis and History of Twardowski's Theory of Actions and Products, [w:] The Golden Age of Polish Philosophy. Kazimierz Twardowski's Philosophical Legacy, S. Lapointe, J. Woleński, M. Marion, W. Miskiewicz (red.), Dordrecht 2009, s. $33-42$.

Brentano F., Deskriptive Psychologie, Hamburg 1982.

Brentano F., Psychologia z empirycznego punktu widzenia, tłum., wstęp i przypisy W. Galewicz, Warszawa 1999.

Chrudzimski A., Intentionalitätstheorie beim frühen Brentano, Dordrecht 2001.

Chudy W., Zagadnienie naoczności aktów poznawczych, „Roczniki Filozoficzne” 29 (1981), nr 1, s. 165-232.

Dąbrowski M.A., Bibliografia prac Leopolda Blausteina, „Roczniki Filozoficzne” 29 (1981), nr 1, s. 244-254.

Dilthey W., Ideen über eine beschreibende und zergliedernde Psychologie, [w:] idem, Gesammelte Schriften, cz. 5. Die Geistige Welt. Einleitung in die Philosophie des Lebens, Erste Hälfte, Leipzig-Berlin 1924, s. 139-240.

Fisette D., Stumpf and Husserl on Phenomenology and Descriptive Psychology, „Gestalt Theory" 31 (2009), nr 2, s. 175-190.

Gilicka M., Leopolda Blausteina krytyka fenomenologii, „Folia Philosophica” 38 (2017), s. $105-114$.

Hopkins B.C., Phenomenological Cognition of the A Priori: Husserl's Method of „Seeing Essences" (Wesenserschauung), [w:] Husserl in Contemporary Context, B.C. Hopkins (red.), Dordrecht 1997, s. 151-178 (https://doi.org/10.1007/978-94-017-1804-2_8).

Husserl E., Badania logiczne, t. 2, Badania dotyczace fenomenologii i teorii poznania, cz. 1, tłum., wstęp i przypisy J. Sidorek, przekład przejrzał A. Półtawski, Warszawa 2000.

Husserl E., Briefwechsel. Bd. III. Die Göttinger Schule, in Verbindung mit E. Schuhmann, K. Schuhmann (red.), Dordrecht 1994.

Husserl E., Idee czystej fenomenologii i fenomenologicznej filozofii, tłum. D. Gierulanka, Warszawa 1967. 
Husserl E., Phänomenologische Psychologie. Vorlesungen Sommersemester 1925, W. Biemel (red.), Husserliana: Edmund Husserl Gesammelte Werte, cz. 9, Den Haag 1968.

Ingarden R., Dzieje mojej „kariery uniwersyteckiej”, „Kwartalnik Filozoficzny” 27 (1999), nr 2, s. 183-201.

Ingarden R., Korespondencja Romana Witolda Ingardena z Kazimierzem Twardowskim, R., Kuliniak, D. Leszczyna, M. Pandura (red.), Kęty 2016.

Ingarden R., Leopold Blaustein - teoretyk radia i filmu, ,Zeszyty Prasoznawcze” 4 (1963), nr 3, s. 86-93.

Jadacki J.J., Życiorysy niedokończone, [w:] ... a Madrości zło nie przemoże, J.J. Jadacki, B. Markiewicz (red.), Warszawa 1993, s. 159-180.

Jadczak R., Koleje starań o profesurę dla Romana Ingardena, „Kwartalnik Filozoficzny" 27 (1999), nr 2, s. 229-242.

Jadczak R., Uczeń i nauczyciel: Z listów Leopolda Blausteina do Kazimierza Twardowskiego z lat 1927-1930, [w:] ... a Madrości zło nie przemoże, J.J. Jadacki, B. Markiewicz (red.), Warszawa 1993, s. 19-27.

Jadczak R., Wokót wniosku o profesure dla Romana Ingardena we Lwowie, „Ruch Filozoficzny" 51 (1995), nr 3-4, s. 268-274.

Martinelli R., A Philosopher in the Lab. Carl Stumpf on Philosophy and Experimental Sciences, „Philosophia Scientiæ” 19 (2105), nr 3, s. 23-43.

Miskiewicz W., Leopold Blaustein's Analytical Phenomenology, [w:] The Golden Age of Polish Philosophy. Kazimierz Twardowski's Philosophical Legacy, S. Lapointe, J. Woleński, M. Marion, W. Miskiewicz (red.), Dordrecht 2009, s. 181-188.

Pazura S., Blaustein, Leopold, [w:] Stownik Filozofów, t. 1, I. Krońska (red.), Warszawa 1966, s. 90.

Płotka W., Early Phenomenology in Poland (1895-1945): Origins, Development, and Breakdown, ,Studies in East European Thought” 69 (2017), nr 1, s. $79-91$ (https:// doi.org/10.1007/s11212-017-9274-0).

Płotka W., Fenomenologia jako filozofia mniejsza. Rozważania wokót sporów o metode Husserla, Warszawa 2019.

Pokropski M., Leopold Blaustein's Critique of Husserl's Early Theory of Intentional Act, Object and Content. „Studia Phaenomenologica” 15 (2015), s. 93-103 (https:// doi.org/10.5840/studphaen2015156).

Ricoeur P., A l'école de la phénoménologie, Paris 1987.

Rosińska Z., Blaustein. Koncepcja odbioru mediów, Warszawa 2001.

Rosińska Z., Leopold Blaustein — styk psychologii i estetyki, [w:] L. Blaustein, Wybór pism estetycznych, Z. Rosińska (red.), Kraków 2005, s. VII-LII.

Röd W., Wilhelm Dilthey a filozofia hermeneutyczna, „Studia Philosophica Wratislaviensia" 7 (2012), nr 1, s. 93-104.

Rzepa T., Psychologia w szkole lwowsko-warszawskiej, „Przegląd Filozoficzny — Nowa Seria" 1 (1992), nr 1, s. 35-45.

Rzepa T., Psychologiczne poglady Kazimierza Twardowskiego, „Studia Philosophiae Christianae" 27 (1991), nr 2, s. 163-175.

Schaar M. van der, Kazimierz Twardowski: A Grammar for Philosophy, Leiden 2015.

Schuhmann K., Husserl-Chronik. Denk- und Lebensweg Edmund Husserls, Den Haag 1977. 
Smith B., Austrian Philosophy. The Legacy of Franz Brentano, Chicago 1994.

Stumpf C., Carl Stumpf, [w:] Philosophie der Gegenwart in Selbstdarstellungen, cz. 5, R. Schmidt (red.), Leipzig 1924, s. 205-265.

Stumpf C., Erscheinungen und psychische Funktionen, Berlin 1906.

Stumpf C., Psychologie und Erkenntnistheorie, „Abhandlungen der Königlich Bayerischen Akademie der Wissenschaften" 19 (1891), nr 2, s. 465-516.

Stumpf C., Zur Einteilung der Wissenschaften, Berlin 1906.

Twardowski K., Ankieta w sprawie nauczania propedeutyki filozoficznej w gimnazjach, „Przegląd Filozoficzny” 6 (1903), nr 1, s. 111-113.

Twardowski K., Autobiografia filozoficzna, „Przegląd Filozoficzny — Nowa Seria” 1 (1992), nr 1, s. 19-33.

Twardowski K., Dzienniki. Część II 1928-1936, R. Jadczak (red.), Warszawa 1997.

Twardowski K., Wybrane pisma filozoficzne, Warszawa 1965.

Wieczorek K., Leopolda Blausteina interpretacja świata zjawiskowego, „Studia z Filozofii Polskiej" 1 (2006), s. 151-163.

Woleński J., Brentanian Motives in Kazimierz Twardowski and His Students, [w:] The Significance of the Lvov-Warsaw School in the European Culture, A. Brożek, F. Stadler, J. Woleńsk (red.), Dordrecht 2017, s. 47-64 (https://doi.org/10.1007/978-3-31952869-4_4).

Woleński J., Filozoficzna szkoła lwowsko-warszawska, Warszawa 1985.

Woleński J., Szkoła lwowsko-warszawska: między brentanizmem a pozytywizmem, „Principia" 8-9 (1994), s. 69-89.

Woleński J., Żydzi w filozofii polskiej, „Studia z Filozofii Polskiej” 5 (2010), s. 13-33. 